\title{
Governance Issues on Earning Management: A Case of Manufacturing Industry
}

\author{
Halil Paino,", Tjut Intan Teuku Iskandar ${ }^{2}$ \\ ${ }^{1}$ Faculty of Accountancy, University Teknologi MARA, Malaysia \\ ${ }^{2}$ Federation of Malaysia Manufacturer, Kuala Lumpur, Malaysia
}

Received August 24, 2021; Revised October 26, 2021; Accepted November 15, 2021

\section{Cite This Paper in the following Citation Styles}

(a): [1] Halil Paino, Tjut Intan Teuku Iskandar, "Governance Issues on Earning Management: A Case of Manufacturing Industry," Universal Journal of Accounting and Finance, Vol. 9, No. 6, pp. 1582-1593, 2021. DOI: 10.13189/ujaf.2021.090635.

(b): Halil Paino, Tjut Intan Teuku Iskandar (2021). Governance Issues on Earning Management: A Case of Manufacturing Industry. Universal Journal of Accounting and Finance, 9(6), 1582-1593. DOI: 10.13189/ujaf.2021.090635.

Copyright $\bigcirc 2021$ by authors, all rights reserved. Authors agree that this article remains permanently open access under the terms of the Creative Commons Attribution License 4.0 International License

\begin{abstract}
Earnings management is a technique used by the management of an organization to intentionally manipulate a company's profits in such a way that the figures suit the agreed target and to generate financial results that provide an excessively optimistic view of the company's operation and finances. Due to poor performance, companies are using different strategies to exploit and provide a positive picture of financial and management profitability to look better in the eyes of shareholders and stakeholders, and this is generally referred to as earnings management. This study aims to examine the potential factors of pressure (financial stability and financial target), opportunity (board independence and audit committee), and arrogance (CEO duality and the CEO's picture) that cause earnings management in manufacturing companies in Malaysia. This study used organizations as the unit of analysis while manufacturing companies from the Public Listed Companies (PLCs) were chosen as the research sample. This study found that the proxies of board independence, audit committee, and CEO's picture have a positive relationship with earnings management. Adversely, the indicators of financial stability, financial target, and CEO duality have negative effects on the incidence of earnings management.
\end{abstract}

Keywords Modified Jones Model, Discretionary Accruals, Crowe's Pentagon Model

\section{Introduction}

The International Financial Reporting Standards (IFRS) embodies the highest quality accounting principles to improve financial reporting transparency and comparability (Wahyuningtyas, 2018) [45]. Garrett et al. [20] stated that the idea of financial statements is to inform users about the true and fair status of companies. However, companies in practice tend to mislead people when facing crises by not reporting their current status and manipulating financial reports. Although EM is permitted in most jurisdictions through the Generally Accepted Accounting Principles (GAAP), managers are mostly suspicious of the practices behind their techniques. The ultimate management technique is always linked to earnings manipulation and financial reporting fraud practices such as income smoothing and creative accounting; therefore, researchers have argued that earnings management is good or bad [34].

The incidence of financial scandals and the downfall of well-known firms as a consequence of fraudulent financial statements from earnings management is a core problem for numerous stakeholders who make extensive use of accounting information. For instance, the Enron company's scandal involved the office of three established state-owned accountants, known as Arthur Andersen LLP, which involved in the energy sector manipulated financial statements by reporting company profits of US $\$ 600$ million to which the business actually suffered losses. The 
downfall of Enron was not only destroyed by the organization but also by the US economy, and this consequently hit the world as stock prices dropped dramatically around the world [20].

Organizations are under massive pressure to fulfill expectations for earnings, which are growing over time for public organizations in particular. The high demand to meet earnings target has driven companies to participate in earnings management more than ever. Nonetheless, aggressive earnings management causes a distorted perception of a company's long-term success. Besides, earnings management is a factor that contributes to financial reporting [11].

Deliberate steps taken by organizations to hide a company's real value that is more predominant in developing markets with market defects are often harmful; hence, maintaining accurate financial reporting has become crucial because it not only includes but also impacts multiple financial information stakeholders [23]. The company's problem tends to occur because there are conflicting interests between companies and investors. Companies are driven by profit as a sustainable metric, while investors are more concentrated on earnings per share, which denotes a reflection of potential profitability [1]. In several countries across the globe, earnings management is a challenge for investors and regulators alike. In managing profits, managers will implement certain accounting strategies to alter financial figures in order to manage accruals accounting [10].

\section{Literature Review and Hypothesis Development}

\subsection{Earnings Management}

Earnings management is a mechanism in which financial decisions are made on intentional assumptions that are consistent with the financial reporting process as well as the main objective behind which is referred to as deception, concealment, or data manipulation, thereby giving a boost to earnings management [20]. According to Healy and Wahlen [24], the reason for this conduct is to confuse shareholders and stakeholders in order to extract advantageous outcomes from company contracts using distorted accounting information.

As defined by Chhabra [12], earnings management is the process of management activities that are expressed in a company's financial reporting either to provide an illusion of smooth periodic or annual earnings so as to display high earnings in a specific year at the expense of reducing the recorded earnings in the future or vice versa. As demonstrated by [11], earnings management can be classified into several categories as follows:

1. Earnings management applies to earnings by applying the decision in compliance with accounting principles and corporate regulations and by designing operations in that the predicted firm profit is not adversely affected.

2. Earnings manipulation applies to management undertaking intentional measures to obtain the published earnings for the desired outcome.

3. Earnings fraud applies to the manipulation of profits by violating accounting principles and corporate regulations by designing operations in such a manner as to minimize the expected valuation of the company.

4. Creative accounting applies to earnings manipulation procedures that do not violate accounting rules or corporate legislation due to a lack of appropriate regulations or legislation.

These four concepts offer insights into why earnings management has been applied in several past studies both as a fraudulent and a non-fraudulent action. In general, the ultimate goal and benefit of management practice is to give external parties a clear impression of management success within an organisation.

\subsection{The Pentagon Theory}

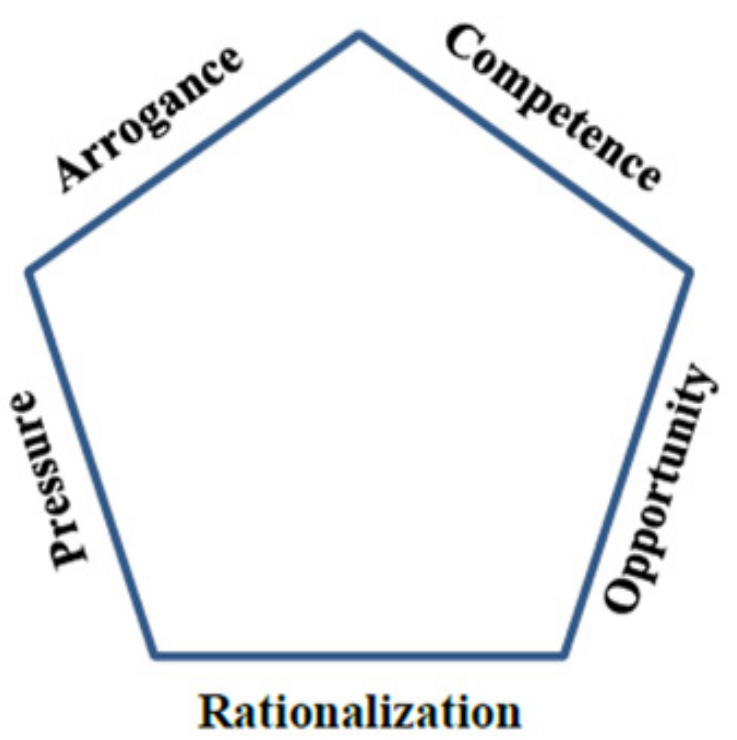

Figure 1. The Pentagon Theory by Crowe Horwart (2011)

Fraud theory is an updated theory that covers the factors that cause fraud. Crowe Horwart [16] proposed the Pentagon theory in 2011 and the five components of this idea are included in the extension of Cressey's [15] Triangle Theory in 1953. In this study, the pentagon theory is used as a guide and seen to be useful to examine the factors behind the incidence of earnings management. This study, however, only focuses on the elements of pressure, opportunity, and arrogance out of the five factors in the pentagon theory to examine their relationships with earnings management. The reason behind the selection of these three factors and exclusion of other factors from Crowe's pentagon theory is that this study aims to 
examine the governance issues that are stemmed from the internal factor of organizations in relation to earnings management.

\subsection{Relationship between Pressure and Earnings Management}

Pressure refers to a situation when someone is involved in deception due to the existence of pressure [19]. In crisis periods, particularly, the risk for criminal behavior becomes considerably greater as a consequence of the burden on companies to reach corporate targets [21]. Moreover, according to Baskaran et al. [11], the management being pressured to fulfil financial expectations and hold the company's stock price up by exploiting the financial reporting.

Management is under pressure to run the business in such a manner that the organization is profitable, and once the business is in a prosperous state, the valuation of the firm will increase [40]. This leads to fraud prevention in an attempt to conceal the wicked security circumstances [43].

A financial target can impact an employee who commits fraud. Excessive pressure on management or staff to achieve the financial target set by the party responsible for governance or administration, including revenue or possible compensation expectations is, therefore, applied. Moreover, Suryandari et al. [41] claimed that managers are expected to display the best results to fulfill the scheduled goals in carrying out their operations. In the presence of these financial targets, managers are, hence, seeking to reach them in a number of areas, one of which is EM. These pressures resulted managers to take some step to demonstrate that the business is in a reasonable shape rather than its actual condition [19].

\subsection{The Effect of Financial Stability on Earnings Management}

Yendrawati et al. [48] indicated that financial stability has a negative relationship with financial fraud, which contributed to the growth of the company and resulted in lower fraudulent reporting. Apriliana and Agustina [39] proved that the financial stability is likely to affect false financial statements. Managers are under pressure to conduct false financial statements as financial stability becomes challenged by the condition of the market, business, and the circumstance of the operational company. The findings reported by Supri et al. [40] have also shown that the dimension of constraint imposed by financial stability has a substantial positive impact on false financial statements that originated from earnings management.

Besides, based on the study by Wahyuningtyas et al. [46], financial stability has an enormous upshot on earnings management, by which the higher the degree of uncertainty in the organization's situation, the larger the propensity of the organization to deceive on financial reporting using an earnings management proxy. Financial stability affects earnings management; hence, the hypothesis of this study based on the literature review from the previous studies is formed as follows:

H1: There is a positive relationship between financial stability and the incidence of earnings management in the manufacturing industry.

\subsection{The Effect of Financial Target on Earnings Management}

Management may experience pressure to manage profits by changing the company's accounting procedures to fulfill financial targets so as to hold the company's stock prices high. Many managers obtain compensation on the basis of financial growth, while some may be entitled to stock options as the stock price rises. Based on the study by Evana et al. [19], the application of a financial target proxy does not impact fraudulent financial statements arising from earnings management.

Adversely, the studies by Taufiq Akbar [4] and Nanda et al. [33] suggest that the financial target measured using the ROA ratio has an impact on the identification of false financial statements. In a study by [37], it was found that the specific rewards for earnings management in Fiji are management compensation rewards, loan cost incentives, motivation to reach goals and raise (or decrease), and regulatory benefits (or costs). However, management pay was reported to be the most prominent motivation to control profits in Fiji. Thus, the following hypothesis is as follows:

$\mathrm{H} 2$ : There is a positive relationship between financial target and the incidence of earnings management in the manufacturing industry.

\subsection{Relationship between Opportunity and Earnings Management}

The most important concern outlined is the need to improve the effectiveness of corporate governance [26]. Enhanced corporate governance structures should be improved including the gap between owners and management $[45,49]$. The value of corporate governance structures, such as the arrangement and organization, is aimed at ensuring that the Boards carry out their supervisory duties properly in that the absence of effective and efficient corporate governance elements.

Al-Absy et al. [6] indicated that, in order to address the conflict of interests between agent and principal, numerous CG reforms and principles have been established around the world and in Malaysia. However, in Malaysia, CG structures are currently ineffective to prevent EM; thus, further reforms are required [47]. 
Various studies in the area of corporate governance have disputed the suspicion on the part of the corporate management of the same series of studies, by which as per the accepted procedures, no overall declaration to lower earnings management has been made [32]. Consequently, the CG issues have created opportunities for opportunistic managers to be involved in EM to alter the financial information for their own benefits and gain the shareholders' trust.

\subsection{The Effect of Board Independence on Earnings Management}

A variety of studies have focused on the connection between the governance of the board and EM [22]. Most independent directors on the board of many different organizations commit little resources to strenuous investigative activities unless the board of directors comes from the same sector [14].

The interaction between CG processes and earnings control had been examined. According to Iraya et al [25], the results revealed a detrimental association between the scale of the group, the integrity of the group, and the ownership framework of earnings management. Talbi et al. [42] found that the board independence contributed to a vital part in earnings' treatment.

Man and Wong [31] described that the board independence provides better oversight over the management's exploitations over earnings. Meanwhile, $\mathrm{Al}$ Azeez et al. [5] conveyed that board independence has a direct effect on lessening the earnings management's practices in safeguarding the shareholders' interests. However, the findings by Akhbar, T. (2016) have shown that board independence may not help reduce the incidence of earnings management, which appeared to have an insignificant but positive relationship with EM. The third hypothesis endorsed is as follows:

H3: There is a negative relationship between board independence and the incidence of earnings management in the manufacturing industry.

\subsection{The Effect of Audit Committee on Earnings Management}

The control of financial statements can be carried out efficiently by the Board's audit committees. Several studies have established the prominent role of audit committees in controlling the process and ensuring the standard of financial reporting [28]. Numerous previous studies have further discussed the problem involving the audit committee and earnings control [12]. This has also been proven by Al-Absy et al. [6], who found a positive relationship between the audit committee and the existence of EM. In addition to the board of directors, [47] also reviewed audit committee and ethnic diversity.

Amar [9] and Sharma and Kuang [38] documented the connotation of independent audit committees with enhanced financial reporting efficiency. The recruitment of the audit committee members will prevent future cases of wrongdoing if the members carry out their duties fairly and faithfully. Accordingly, the fourth hypothesis is formed as:

H4: There is a negative relationship between audit committee and the incidence of earnings management in the manufacturing industry.

\subsection{Relationship between Arrogance and Earnings Management}

MCCG 2017 stresses that all directors will carry out their roles and obligations fairly at all times as trustees in the interests of a company. Any director is obligated to keep abreast of his duties as director and of the actions, business practices, and growth of the firm. As explained by Geis [49], a variation of several factors is causing certain individuals to commit fraud. For instance, personality, which refers to qualities that define a particular person, is one of the most important influences.

Arrogance is an attitude of superiority towards possessing such privileges and a belief that the internal control or discipline of the organization should not apply to itself. Fraudsters generally believe that they are safe to conduct crimes without fear of penalties that would ensnare them. Due to the high degree of pride and confidence, fraudsters, such as the CEOs will contribute to earnings management. Moreover, when there is a duality between the positions of the CEO and the Chairman, this will give rise to strong power and a major impact on the board's decisions, which will weaken the strength of the board's power [50].

As reported by Nuanpradit [51], the newly named CEOs are more likely to exploit sales revenues with just the upward path within the first three years of operation. Meanwhile, the recently named CEOs that concurrently serve as chairman prefer to engage in upward or downward sales-driven REM. The person who conducts EM or REM must have high confidence and ego; as highlighted by Geis [49], the most prevalent motivations for fraud are the feeling of superiority and the greed for power.

\subsection{The Effect of CEO Duality on Earnings Management}

Practice 1.3 of the MCCG encourages the position of Chairman of the Board and CEO to be served by two separate people. Separation in this regard is important, as both positions are distinct, have different requirements, and represent different primary communities. The study by Mohamad et al. [32] found that CEO duality has an adverse effect to EM. Furthermore, Alam et al.[7] demonstrated a significant focus on the role of CEO 
duality in the reduction of EM.

However, Triki, D. (2018) [17] and Al-Sraheen and Alkhatib [8] discovered a significant positive correlation between CEO duality and discretionary accruals. Al Azeez et al. [5] also showed that CEO duality has a substantial effect in enhancing the ability of the board of directors to track, regulate, and boost the directors' information processing capability. In the case of CEO duality measure, the findings of the current study, however, have shown a favorable relationship with earnings control. Therefore, the fifth hypothesis is:

H5: There is a positive relationship between CEO duality and the incidence of earnings management in the manufacturing industry.

\subsection{The Effect of CEO's picture on Earnings Management}

The number of photographs in the annual report of the CEO of the organization may denote the pride and dominance that the CEO holds based on Crowe's fraud pentagon feature, i.e. the pride. The CEO is supposed to show all the prestige and role he has in the company, according to [13], because he or she does not want to risk the prestige. This is in line with [16] concepts in which the CEO believes that any internal oversight is not available to him because of the high degree of pride and dominance that can lead to deception due to his status and ego. While Nanda et al. [33] reported that CEO images have little impact on the detection of fraudulent financial reporting, [38], however, found that the regular number of
CEOs influences the potential for financial fraud. Besides, the research outcome by [29] also shows that narcissistic CEOs (one of the metrics measured by CEO's picture) are probable to occupy in earnings manipulation. Hence, the sixth hypothesis is:

H6: There is a positive relationship between CEO's picture and the incidence of earnings management in the manufacturing industry.

\section{Theoretical Framework}

The key objective of the study is to examine the possible aspects that can cause the occurrence of earnings management. This study primarily focuses on the three elements from Crowe's pentagon theory as the underlying independent variables, namely pressure (financial stability and financial target), opportunity (board independence and audit committee), and arrogance (CEO duality and CEO's picture). All of the independent variables will be tested to examine their relationships with the dependent variable, which is earnings management.

Modified Jones model was used as a measurement of the dependent variable in measuring the discretionary accruals of manufacturing companies in Bursa Malaysia. Figure 2 shows a summary of the independent variables and the dependent variables that illustrates the connection between these variables as designed during the hypothesis's development.

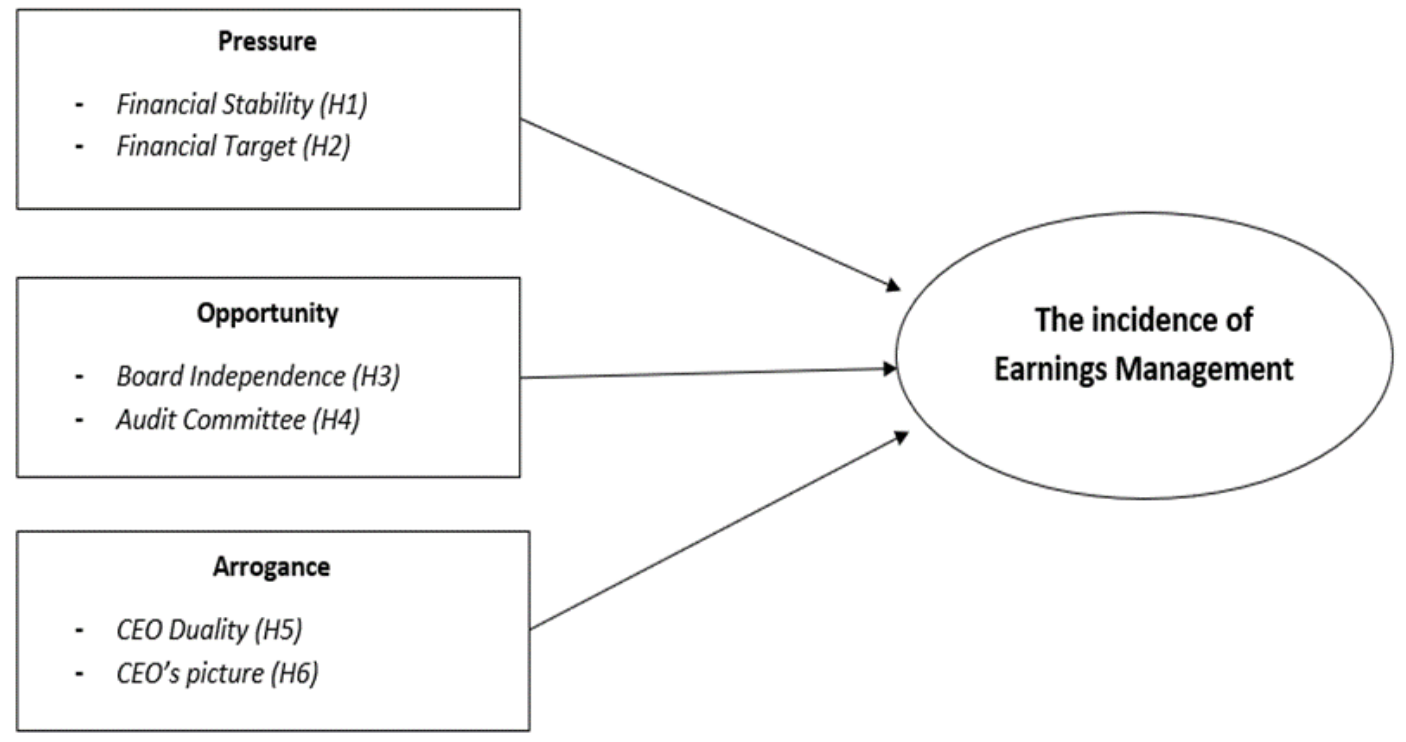

Figure 2. Theoretical Framework 


\section{Research Background}

\subsection{Background of the Study}

The Association of Certified Fraud Examiners (ACFE) had discovered 2,690 cases of occupational fraud in 2018 and 2,504 cases of occupational fraud in 2020 involving 125 countries. Then, the investigation report by the Global Economic Crime and Fraud Survey conducted by [35], accounting or the financial statement of fraud score cases were ranked fifth in the global out of 13 main fraud cases. The results from both researches underline the serious impact of occupational fraud on organizations worldwide, thereby contributing to huge losses to the nation. The statistical report by ACFE in 2020 shows that Malaysia was ranked the fifth in the number of reported occupational fraud cases (19 out of 198 cases) in Asia-Pacific countries from January 2018 to September 2019. In addition, manufacturing companies recorded the greatest number of reported occupational fraud cases in the Asia-Pacific region with a median loss of $\$ 500,000$ [2] and $\$ 400,000$ [3] compared to other industries. ACFE 2020 in Asia Pacific Edition has also reported that financial statement fraud was ranked fifth in terms of occupational fraud cases (14\%) with a median loss of $\$ 3,000,000$.

The ACFE reports depict the serious impacts of earnings management that could lead to financial statement fraud in the manufacturing sector and this may worsen during crises. Recently, Malaysian manufacturing companies have suffered demand downturns due to the coronavirus pandemic. Compared to the previous month, both production and new orders have also slowed down further in October 2020 and this is expected to remain in the following months if the COVID-19 infection does not improve in the region. According to Chief Business Economist of IHS Markit, Chris Williamson, the rise in COVID-19 has raised worries among manufacturers over supply and demand constraints and reduced business confidence (Kamarulzaman \& Williamson, 2020) [26]. Due to these issues, manufacturing firms tend to perform earnings management to cover the real financial and economic conditions so as to signal the existing and new potential shareholders that companies appear to be performing well even during crisis situations.

\subsection{Research Objectives}

The main objective of this study is to examine the potential factors that cause the incidence of earnings management in manufacturing companies in Malaysia. The objectives of this study are as follows:

1. To examine the relationship between pressure (financial target and financial stability) and the incidence of earnings management in the manufacturing industry.
2. To examine the relationship between opportunity (board independence and audit committee) and the incidence of earnings management in the manufacturing industry.

3. To examine the relationship between arrogance (CEO duality and CEO's picture) and the incidence of earnings management in the manufacturing industry.

\subsection{Research Questions}

This study intends to answer the following questions:

1. Does pressure (financial target and financial stability) cause the incidence of earnings management in the manufacturing industry?

2. Does opportunity (board independence and audit committee) cause the incidence of earnings management in the manufacturing industry?

3. Does arrogance (CEO duality and CEO's picture), cause the incidence of earnings management in the manufacturing industry?

\section{Research Methodology}

\subsection{Sample Selection}

This study used organizations as the unit of analysis. Samples were selected from the listed manufacturing companies (Public Listed Companies (PLC)) as per Bursa Malaysia listing (Malaysian Exchange). The sampling technique was designed under certain sampling criteria as follows:

1. PLC manufacturing companies listed on Bursa Malaysia, which had published their audited annual financial statements at least a year between 2015 and 2018.

2. Annual financial reports with data relating to the research variables (overall data available in publications from 2015 to 2018.

Based on the sampling criteria above, 99 out of 135 companies sought for this study have met the criteria to be selected as the sample in this study.

\section{Findings}

\subsection{Descriptive Statistics and Normality Test}

The analysis for this test was conducted based on a sample size of 99 PLC. As shown in Table 1, the minimum score for the dependent variable was -1.34 . Additionally, the mean score recorded in this study was -.3715 , with the median was -.3715 and the standard deviation was .29039.

In this study, three (3) outliers of the sample data were excluded from the analysis, leaving a total of 393 as the 
sample data. After performing data transformation, the skewness for the dependent variable of earnings management was -.078 , indicating that the data were slightly negatively skewed, by which the negative scores indicate a build-up of high scores or larger scores.

\subsection{Pearson's Correlation Coefficient Test}

The Pearson's correlation matrix is presented at Table 2. This correlation is based on the assessment of variations in one variable with another variable. Basically, the correlation between two variables depicts a perfect positive correlation of positive $1(+1.00)$, or a perfect negative correlation of negative $1(-1.00)$ (Sekaran and Bougie, 2016) [36].

Table 2 illustrates the correlation results between the variables in this study. All of the independent variables yielded little correlation with earnings management
(DACC) by which the value of correlation lies between .00 and .30 . The pressure factor showed a significant little negative correlation between financial target (FTAR) and earnings management $(r=-.096, p$ $<.05$ ), while financial stability also showed a significant little negative correlation with earnings management $(r=$ $-.096, p<.001)$. Subsequently, the opportunity factor indicated no significant little positive correlation between board independence (BIND) and earnings management $(r$ $=.035, p>.05$ ), whereas audit (AUDC) committee also indicated no significant little positive correlation with earnings management $(r=.026, p>.05)$. Lastly, the arrogance factor revealed no significant little negative correlation between CEO duality (CDUAL) and earnings management $(r=-.078, p>.05)$, including CEO's picture (CPICT) that also had no significant little positive correlation with earnings management $(r=.046, p>.05)$.

Table 1. Descriptive Statistics and Normality Test

\begin{tabular}{|c|c|c|c|c|c|c|c|c|c|}
\hline & & \multicolumn{5}{|c|}{ Descriptive Statistics } & \multicolumn{3}{|c|}{ Normality Test } \\
\hline & & Min. & Max. & Mean & Median & Std. D & & Skewness & Kurtosis \\
\hline \multicolumn{2}{|c|}{$\begin{array}{c}\text { Discretionary } \\
\text { Accruals }\end{array}$} & -1.34 & .60 & -.3715 & -.3590 & .29039 & & -.078 & .780 \\
\hline & & DACC & FTAR & FSTA & BIND & & AUDC & CDUAL & CPICT \\
\hline DACC & $\begin{array}{c}\text { Pearson's } \\
\text { correlation sig. }\end{array}$ & $\begin{array}{c}1.000 \\
.\end{array}$ & & & & & & & \\
\hline FTAR & $\begin{array}{c}\text { Pearson's } \\
\text { correlation sig. }\end{array}$ & $\begin{array}{c}-.096^{*} \\
.029\end{array}$ & $\begin{array}{c}1.000 \\
.\end{array}$ & & & & & & \\
\hline FSTA & $\begin{array}{c}\text { Pearson's } \\
\text { correlation sig. }\end{array}$ & $\begin{array}{c}-.185^{* *} \\
.000\end{array}$ & $\begin{array}{c}.350 * * \\
.000\end{array}$ & $\begin{array}{c}1.000 \\
.\end{array}$ & & & & & \\
\hline BIND & $\begin{array}{c}\text { Pearson's } \\
\text { correlation sig. }\end{array}$ & $\begin{array}{l}.035 \\
.245\end{array}$ & $\begin{array}{c}-.103 * \\
.021\end{array}$ & $\begin{array}{l}.011 \\
.416\end{array}$ & $\begin{array}{c}1.000 \\
.\end{array}$ & & & & \\
\hline AUDC & $\begin{array}{c}\text { Pearson's } \\
\text { correlation sig. }\end{array}$ & $\begin{array}{l}.026 \\
.302\end{array}$ & $\begin{array}{c}.179 * * \\
.000\end{array}$ & $\begin{array}{r}-.023 \\
.326\end{array}$ & $\begin{array}{l}.082 \\
.051\end{array}$ & & $\begin{array}{c}1.000 \\
.\end{array}$ & & \\
\hline CDUAL & $\begin{array}{c}\text { Pearson's } \\
\text { correlation sig. }\end{array}$ & $\begin{array}{r}-.078 \\
.060\end{array}$ & $\begin{array}{c}-.083 * \\
.050\end{array}$ & $\begin{array}{r}-.005 \\
.463\end{array}$ & $\begin{array}{r}-.073 \\
.075\end{array}$ & & $\begin{array}{c}-.088^{*} \\
.040\end{array}$ & $\begin{array}{c}1.000 \\
.\end{array}$ & \\
\hline CPICT & $\begin{array}{c}\text { Pearson's } \\
\text { correlation sig. }\end{array}$ & $\begin{array}{l}.046 \\
.182 \\
\end{array}$ & $\begin{array}{c}.105^{*} \\
.019\end{array}$ & $\begin{array}{l}.033 \\
.254\end{array}$ & $\begin{array}{l}.072 \\
.078\end{array}$ & & $\begin{array}{c}.227 * * \\
.000\end{array}$ & $\begin{array}{c}-.139 * \\
.003\end{array}$ & $\begin{array}{c}1.000 \\
.\end{array}$ \\
\hline $\begin{array}{l}\text { e: } \\
\text { Correlati } \\
\text { orrelatio }\end{array}$ & $\begin{array}{l}\text { is significant at } \\
\text { significant at } t\end{array}$ & $\begin{array}{l}\mathrm{t} \text { the } 0.011 \\
\text { the } 0.05 \mathrm{le}\end{array}$ & $\begin{array}{l}\text { (1-tailed } \\
\text { 1-tailed) }\end{array}$ & & & & & & \\
\hline
\end{tabular}




\subsection{Multiple Regression Analysis}

Multiple regression analysis presents a way to determine the degree and nature of the association between the independent variables and the dependent variable in an analytical manner. Throughout the prediction of the dependent variable, the regression coefficients demonstrate the relative value of each independent (Sekaran and Bougie, 2016) [36]. In this study, the multiple regression analysis was conducted to predict the incidence of earnings management in the manufacturing industry of Bursa Malaysia.

Table 3 illustrates the summary statistics of the $R^{2}$ of the multiple regression model. The $R^{2}$ value of .045 represents $4.5 \%$ of the total variation in the dependent variable, and this indicates that $4.5 \%$ of the variation in earnings management was explained by pressure (financial target and financial stability), opportunity (board independence and audit committee), and opportunity (CEO duality and CEO's picture), whereas the remaining $95.5 \%$ was explained by other factors.

ANOVA was conducted to examine the significance level of the model. Table 4 shows a summary of the ANOVA results in this study. The value of $\mathrm{F}_{\text {observed }(6,386)}=$ $3.029, p<.05$ and the value for $\mathrm{F}_{\text {critical }(6,386)}=2.10$ showed that the $F_{\text {observed }}$ values are greater than the $F_{\text {critcal }}$ value, indicating a significant linear relationship between the incidence of earnings management and at least one or all of the independent variables. This implies that at least one of the independent variables of pressure (financial target and financial stability), opportunity (board independence and audit committee), and opportunity (CEO duality and CEO's picture) can impact the incidence of EM.

Table 3. Summary Statistics of the $R^{2}$ of the Multiple Regression Model

\begin{tabular}{|c|c|c|c|c|}
\hline Model & $\mathbf{R}$ & R Square & $\begin{array}{l}\text { Adjusted } \\
\text { R Square }\end{array}$ & Std. Error of the Estimate \\
\hline 1 & $.212^{\mathrm{a}}$ & .045 & .030 & .28598 \\
\hline \multicolumn{5}{|c|}{ a. Predictors: (Constant), CEO's picture, Financial Stability, Board Independence, CEO Duality, Audit Committee, Financial Target } \\
\hline
\end{tabular}

Table 4. Summary Statistics of ANOVA

\begin{tabular}{|c|c|c|c|c|c|c|}
\hline & Model & Sum of Squares & df & Mean Square & $\mathbf{F}$ & Sig. \\
\hline \multirow{3}{*}{1} & Regression & 1.486 & 6 & .248 & 3.029 & $.007^{\mathrm{b}}$ \\
\hline & Residual & 31.569 & 386 & .082 & & \\
\hline & Total & 33.055 & 392 & & & \\
\hline & & a. Dependent & ble: D & ary Accruals & & \\
\hline
\end{tabular}

Table 5. Summary Statistics of Multiple Regression

\begin{tabular}{|c|c|c|c|c|c|c|}
\hline & \multirow{2}{*}{ Model } & \multicolumn{2}{|c|}{ Unstandardized Coefficients } & \multirow{2}{*}{$\frac{\text { Standardized Coefficients }}{\text { Beta }}$} & \multirow{2}{*}{$\mathbf{t}$} & \multirow{2}{*}{ Sig. } \\
\hline & & $\mathrm{B}$ & Std. Error & & & \\
\hline \multirow{7}{*}{1} & (Constant) & -.402 & .109 & & -3.682 & .000 \\
\hline & $\begin{array}{l}\text { Financial } \\
\text { Stability }\end{array}$ & -.233 & .073 & -.171 & -3.194 & .002 \\
\hline & Financial Target & -.124 & .147 & -.047 & -.847 & .398 \\
\hline & $\begin{array}{c}\text { Board } \\
\text { Independence }\end{array}$ & .054 & .121 & .022 & .445 & .657 \\
\hline & Audit Committee & .007 & .030 & .013 & .244 & .807 \\
\hline & CEO Duality & -.073 & .050 & -.075 & -1.475 & .141 \\
\hline & CEO's Picture & .007 & .008 & .042 & .805 & .421 \\
\hline
\end{tabular}

a. Dependent Variable: Discretionary Accruals 
Table 5 shows the summary statistics of multiple regression. The regression equation of this study is formulated as follows:

$$
\begin{aligned}
\mathrm{EM} & =-.402-.233(\text { FSTAB})-.124 \text { (FTAR) }+.054 \text { (BIND) } \\
& +.007 \text { (AUDC) }-.073(\text { CDUAL })+.007 \text { (CPICT) }
\end{aligned}
$$

Based on the results, only three independent variables $(\mathrm{H} 3, \mathrm{H} 4$, and $\mathrm{H} 6)$ have a positive influence on earnings management, and these independent variables are board independence $\left(\beta_{3}=.054, t=.022, p>.05\right)$, audit committee $\left(\beta_{4}=.007, t=.013, p>.05\right)$, and CEO's picture $\left(\beta_{6}=.007, t=.013, p>.05\right)$. However, all of these variables were reportedly insignificant $(p>.05)$. Meanwhile, the other three independent variables (H1, H2, and H5) have a negative influence on earnings management, such as financial stability $\left(\beta_{1}=-.402, t\right.$ $=.022, p<.05)$, financial target $\left(\beta_{2}=-.124, t=-.047\right.$, $p>.05)$, and CEO duality $\left(\beta_{5}=-.073, t=-.075, p>.05\right)$. Only one variable, which is financial stability, indicated a significant effect on earnings management. Correspondingly, Table 4.6 summarizes the findings of the hypotheses.

\section{Discussion of the Findings}

The analysis was conducted based on a sample size of 99 PLC listed on the Bursa Malaysia and the sample data from 2015 to 2018 were collected and analyzed, contributing to a total of 396 sample data.

The result in $\mathrm{H}_{1}$ shows that EM will reduce by $40.2 \%$ for each increase in financial stability $\left(\beta_{1}=-.402, t=.022\right.$, $p<.05)$. This result is consistent with [47] who indicated that financial stability has a negative relationship with financial fraud that arises from EM. However, this result contradicts the findings by [45], by which the higher the degree of uncertainty in the organization's situation, the larger the tendency of the organization to deceive on financial reporting using earnings management. Similarly, the result also opposes the findings by [38] that financial stability is likely to affect false financial statements and contradicts [39], who asserted that the dimension of constraints imposed by financial stability has a substantial positive impact on false financial statements that originated from earnings management. Based on the indicator of financial stability as a proxy of pressure factor, it can be concluded that the pressure factor has a significant negative relationship with the incidence of EM.

Based on the result in $\mathrm{H}_{2}$, the regression analysis coefficient indicates that EM will decrease by $12.4 \%$ for each increase in financial target $\left(\beta_{2}=-.124, t=-.047\right.$, $p>.05)$. This is persistent with [19], which outlines that the financial target proxy does not impact fraudulent financial statements rising from EM. Adversely, the studies by [4] and [33] contradict this study, since they suggested that the financial target measured using the ROA ratio has an impact on the identification of false financial statements arising from EM. Based on the indicator of financial target as a proxy of pressure factor, it can be determined that the pressure factor has no relationship with the incidence of EM due to insignificant result.

Based on the result in $\mathrm{H}_{3}$, the regression analysis coefficient reveals that earnings management will increase by $5.4 \%$ for each increase in board independence $\left(\beta_{3}\right.$ $=.054, t=.022, p>.05)$. This shows that the increased percentage of independent directors on board composition contributes to the ineffectiveness of the monitoring function. This is consistent with the finding by [22], that the independent directors will not enhance the oversight of boards. However, this result contradicts with Man and [31] and [5] that the board independence provides better oversight over the management's exploitation of earnings and has a direct effect on the reduction of earnings management. In line with board independence as a proxy of opportunity, it can be concluded that the opportunity factor has a no relationship with the incidence of EM due to insignificant result.

Similarly, the findings in $\mathrm{H}_{4}$ discover that EM will also increase by $0.7 \%$ for each increase in audit committee $\left(\beta_{4}\right.$ $=.007, t=.013, p>.05)$. Adverse results were found in the studies conducted by [6] and [46], which demonstrate that audit committee is significant positive correlated with EM. Based on the results by [9] and [38], there is an association of independent audit committees with enhanced financial reporting efficiency. The findings for audit committee as a proxy of opportunity for this study demonstrated that the opportunity factor has no relationship with the incidence of EM.

The finding in $\mathrm{H}_{5}$ illustrates that EM will reduce by $7.3 \%$ for each increase in CEO duality $(\beta 5=-.073, \mathrm{t}=$ $-.075, \mathrm{p}>.05$ ). This result contradicts with the findings by [7] and [32], who found a significant negative correlation. In addition, this result also contradicts with Triki, D. (2018) [17], [5] and [8], who discovered a significant positive correlation. The indicator of CEO duality as a proxy of arrogance, it can be assumed that there is a no relationship between arrogance and EM due to insignificant result.

Finally, the multiple regression analysis result in $\mathrm{H}_{6}$ reveals a positive relationship between CEO's picture $\left(\beta_{6}\right.$ $=.007, t=.013, p>.05)$ and the incidence of earnings management, by which the increase in each CEO's picture affects the incidence of EM by $0.7 \%$. This result contradicts with the study by [39] who found that the regular number of CEOs influences the potential for financial fraud resulting from EM. The increase in CEO's picture in the annual report portrays the pride and opportunistic behavior. This arrogance can lead to the misreporting of financial performance. The result from this study also opposes with [29], who asserted that narcissistic CEOs (one of the metrics measured by CEO's picture) are engaged in earnings manipulation. Based on 
the indicator of CEO's picture as a proxy of arrogance factor, it can be asserted that the arrogance factor has no relationship with the incidence of EM due to insignificant result.

\section{Conclusions}

This study was carried out with the main objective to examine the potential factors that cause the incidence of earnings management in manufacturing companies in Malaysia. To measure the incidence and level of earnings management, a prediction model of discretionary accruals from the Modified Jones model was used in this study. The pressure factor was examined based on the indicator of financial stability and financial target for the first objective of the study.

The findings found a significant negative relationship between financial stability and financial target. The findings further indicated that although management under pressure tends to have strong financial stability, the result also showed that management tends to engage less in EM. Based on the measurement of financial stability by asset change (ACHANGE), the higher the asset value, the higher its contribution to the growth of the company. The financial position of a company would, thus, be more stable merely due to management efficiency instead of management manipulation in order to obtain intention from the users of financial statements. Yendrawati et al. [48] also suggested that financial stability leads to company growth.

Apart from the pressure factor, the results indicated that financial target has negatively affects earnings management but insignificant relationship. This depicts that the pressure to achieve targets is not influence EM. Financial target as measured by the return of assets (ROA) shows the profitability of the company. This further indicates that the greater the percentage of ROA, the more efficient the company becomes in managing their asset to generate profits. Correspondingly, Evana et al. [19] has also stated that managers do not treat ROA as a financial target that is impossible to attain; thus, the incidence of financial fraud is not merely caused by ROA.

The second objective of this study aims to investigate the relationship between opportunity and the incidence of earnings management in the manufacturing industry. The results showed that both of the variables have an insignificant positive impact on earnings management. Mohamad et al. [32] suggested that, in order to minimize EM, companies should implement the best practices of CG. The board composition should include and be seated by the right persons with the right skills and knowledge, experience, independence, and diversity.

Finally, the third objective of this study aims to discover the relationship between arrogance and the incidence of earnings management in the manufacturing industry. CEO duality and CEO's picture were used as indicators of the arrogance factor. This study found that CEO duality has an insignificant negative impact on EM, and CEO duality proxy further illustrated that the position of CEO and chairman hold by the same person does not contribute to a personal conflict of interest. The findings of this study also found that CEO's picture has a positive impact on earnings management but with insignificant effects. The weak CG enforcement found in this study contributed to several opportunities for the CEO to commit EM. The theory of Crowe [16] stated that a CEO believing that the internal oversight does not affect him is due to the high degree of pride that could lead to deception due to his status and ego. Overall, these findings coincide with [39], who found that the regular number of CEOs influences the potential for financial fraud.

\section{Acknowledgments}

We are very grateful to experts for their appropriate and constructive suggestions for improvement.

\section{REFERENCES}

[1] Abdulhuseen, A., \& Saedi, A. (2019). Earnings Management and Its Relationship with Stock Returns : An Empirical Study on A Sample Of Qatari Listed Industrial. January.

[2] ACFE. (2018). Report to the Nations - 2018 Global Study on Occupational Fraud and Abuse: Asia Pacific. Asia Pacific Edition, 10, 80.

https://doi.org/http://dx.doi.org/10.2139/ssrn.2222608

[3] ACFE. (2020). Report to the Nations - 2020 Global Study on Occupational Fraud and Abuse: Asia Pacific Edition. 121.

[4] Akbar, T. (2017). Using Pentagon Theory on Manufacturing Companies in. International Journal of Business, Economics and Law, Vol.14, No.5, 106-113.

[5] Al Azeez, H. A. R., Sukoharsono, E. G., Roekhudin, \& Andayani, W. (2019). The impact of board characteristics on earnings management in the international Oil and Gas Corporations. Academy of Accounting and Financial Studies Journal, Vol.23, No.1.

[6] Al-Absy, M. S. M., Ismail, K. N. I. K., Chandren, S., \& Al-Dubai, S. A. A. (2020). Involvement of board chairmen in audit committees and earnings management: Evidence from Malaysia. Journal of Asian Finance, Economics and Business, Vol.7, No.8, 233-246. https://doi.org/10.13106/JAFEB.2020.VOL7.NO8.233

[7] Alam, N., Ramachandran, J., \& Nahomy, A. H. (2020). The impact of corporate governance and agency effect on earnings management - A test of the dual banking system. Research in International Business and Finance, Vol.54, 
101242. https://doi.org/10.1016/j.ribaf.2020.101242

[8] Al-Sraheen, D.A.-D. and Alkhatib, K. (2016), "Proposing a model for limiting earning management practices: the case of Jordanian listed firms", Corporate Board: role, Duties and Composition, Vol. 12, No. 3, 81-84.

[9] Amar, A. Ben. (2014). The Effect of Independence Audit Committee on Earnings Management: The Case in French. International Journal of Academic Research in Accounting, Finance and Management Sciences, Vol.4, No.1, 96-102. https://doi.org/10.6007/IJARAFMS/v4-i1/544

[10] Ayedh, A. M., A. H. Fatima, \& Muslim Har Sani Mohammad. (2019). Earnings Management in Malaysian Companies during the Global Financial Crisis and the Coincidental Effect of IFRS Adoption. Australasian Accounting, Business and Finance Journal, Vol.13, No.1, 4-26. https://doi.org/10.14453/aabfj.v13i1.2

[11] Baskaran, S., Nedunselian, N., Ng, C. H., Mahadi, N., \& Abdul Rasid, S. Z. (2020). Earnings management: a strategic adaptation or deliberate manipulation? Journal of Financial Crime, Vol.27, No.2, 369-386. https://doi.org/10.1108/JFC-07-2019-0098

[12] Chhabra, S. (2016). Earning Management: A Study. Splint International Journal of Professionals, Vol.3, No.11 40-45.

[13] Chyntia Tessa (2016). Fraudulent Financial Reporting: Pengujian Teori Fraud Pentagon Pada Sektor Keuangan Dan Perbankan Di Indonesia. Semarang. Simposium Nasional Akuntansi XIX.Lampung.

[14] Clements, C., Neill, J. D., Wertheim, P., Clements, C., Neill, J. D., \& Wertheim, P. (2015). Multiple directorships, industry relatedness, and corporate governance effectiveness. https://doi.org/10.1108/CG-05-2014-0060

[15] Cressey, D. R. (1953). Other people's money: A study in the social psychology of embezzlement. New Jersey: Patterson Smith.

[16] Crowe, H. (2011). Playing Offence in High Risk Environment - A Sophisticated Approach to Fighting Fraud. Crowe Horwath Publishing, New York.

[17] Triki, D. (2018). Gender diverse board and earnings management: evidence from French listed companies. Sustainability Accounting, Management and Policy Journal, Vol.9, No. 3, 289-312.

https://doi.org/10.1108/SAMPJ-08-2017-0088

[18] Economic, A., Uwuigbe, U., State, O., \& Uwuigbe, O. R. (2015). Assessment of the Effects of Firms Characteristics on Earnings Management of Listed Firms in Nigeria. Asian Economic and Financial Review, Vol.5, No.2, 218-228. https://doi.org/10.18488/journal.aefr/2015.5.2/102.2.218.2 28

[19] Evana, E., Metalia, M., Mirfazli, E., Georgieva, D. V., \& Sastrodiharjo, I. (2019). Business Ethics in Providing Financial Statements: The Testing of Fraud Pentagon Theory on the Manufacturing Sector in Indonesia. Business Ethics and Leadership, Vol.3, No.3, 68-77.

[20] Garrett, K. W. C., Mohamad, S., Shafie, R. Bin, \& Sadiq, M. (2020). International financial reporting standards and earnings management: Comparative study of pre-post full convergence of IFRS in Malaysia. Journal of Critical
Reviews, Vol.7, No.2, 85-89.

https://doi.org/10.31838/jcr.07.02.17

[21] Georgios L. Vousinas. (2019). Advancing theory of fraud: The S.C.O.R.E. Model. Journal of Financial Crime, Vol. 26, No. 1, pp. 372-381.

[22] Germain, L., Galy, N., \& Lee, W. (2014). Journal of Economics and Business Corporate governance reform in Malaysia: Board size, independence and monitoring. Journal of Economics and Business, Vol. 75, 126-162. https://doi.org/10.1016/j.jeconbus.2014.06.003

[23] Gloria, T., \& Emenike, C. (2018). Effect of Earnings Management on Performance of Corporate Organisation In Nigeria. International Journal of Business Management and Economic Review, Vol.1, No.3, 74-87.

[24] Healy, P. M. (1998). A Review of the Earnings Management Literature and Its Implications for Standard Setting. November.

[25] Iraya, C., Cpa, K., Mwangi, M., \& Cpa, K. (2015). The Effect Of Corporate Governance Practices On Earnings Management Of Companies Listed At The Nairobi Securities Exchange. Vol.11, No.1, 169-178. Junxiong, F (2016). The Impact of Split-share Structure Reform on the Earning Management between Pre-IPO and Post-IPO. Securities Market Herald

[26] Jones Jones, J. J. (1991). Earnings management during import relief investigations. Journal of Accounting Research, 29(2), 193-228.

[27] Kamarulzaman, B. F., \& Williamson, C. (2020). Budget 2021 to Help Support Manufacturing Sector. 2020-2022.

[28] Kapoor, N. (2018). Board Characteristics and Earnings Management: A Literature Review for gap analysis in Emerging Economies. Accountancy Business and the Public Interest, Vol 17, 106-131

[29] Kasznik, R. (1999). On the association between voluntary disclosure and earnings management. Journal of Accounting Research, 37(1), 57-81. https://doi.org/10.2307/2491396

[30] Lin, F., Lin, S. W., \& Fang, W. C. (2020). How CEO narcissism affects earnings management behaviors. North American Journal of Economics and Finance, Vol.51, 101080. https://doi.org/10.1016/j.najef.2019.101080

[31] Malaysia, S. C. (2017). Malaysian Code On Corporate Governance (MCCG) 2017. 1-49. -MCCG 2017

[32] Man, C., Kong, H., Wong, B., \& Kong, H. (2013). And Earnings Management : Vol.29, No.2, 391-418.

[33] Mohamad, S., Abdurrahman, A. P., Keong, O. C., \& Garrett, K. W. C. (2020). Corporate governance and earnings management: Evidence from listed malaysian firms. International Journal of Psychosocial Rehabilitation, Vol.24, No.4, 1744-1755. https://doi.org/10.37200/IJPR/V24I4/PR201284

[34] Nanda, S. tri, Salmiah, N., \& Mulyana, D. (2019). Fraudulent Financial Reporting: a Pentagon Fraud Analysis. Jurnal Ilmiah Ekonomi Dan Bisnis, Vol.16, No.2, 122-134. https://doi.org/10.31849/jieb.v16i2.2678

[35] Omar, N., Rahman, R. A., Danbatta, B. L., \& Sulaiman, S. 
(2014). Management Disclosure and Earnings Management Practices in Reducing the Implication Risk. Procedia Social and Behavioral Sciences, Vol.145, 88-96. https://doi.org/10.1016/j.sbspro.2014.06.014

[36] PwC. (2020). Fighting fraud: A never-ending battle. PwC's Global Economic Crime and Fraud.

[37] Rani, P., Hussain, F. F., \& Chand, P. V. (2013). Management Among Listed Firms : Evidence. Vol.7, No.1, 21-32.

[38] Sekaran, U. \& Bougie, R. (2016). Research Methods for Business - A Skill Building Approach. $7^{\text {th }}$ Edi, Wiley Publication, U.K.

[39] Sharma, V. D., \& Kuang, C. (2014). Voluntary Audit Committee Characteristics, Incentives, and Aggressive Earnings Management: Evidence from New Zealand. Vol.18, No.1, 76-89.

[40] Siska Apriliana, \& Linda Agustina. (2017). The Analysis of Fraudulent Financial Reporting Determinant through Fraud Pentagon Approach. Jurnal Dinamika Akuntansi, Vol.9, No.2, 154-165.

[41] Supri, Z., Rura, Y., \& Pontoh, G. T. (2018). Detection of Fraudulent Financial Statements with Fraud. Journal of Research in Business and Management, Vol.6, No.5, 3945 .

[42] Suryandari, N. N. A., Yuesti, A., \& Suryawan, S. (2019). Fraud Risk and Earnings Management. Journal of Management Policies and Practices, Vol.7, No.1, 43-51. https://doi.org/10.15640/jmpp.v7n1a4

[43] Talbi, D., \& Kairouan, U. De. (2015). The Role Of Board Characteristics In Mitigating Management Opportunism: The Case Of Real Earnings Management. Vol.31, No.2, 661-674.

[44] Tarigan, A. J. N. (2020). Fraudulent Financial Statement Detection with Fraud Pentagon Analysis In Banking Companies In Five Asia- Pacific Countries.
[45] The Association of Certified Fraud Examiners. (2020). Report to the nations: Global study on occupational fraud and abuse. Global Fraud Study, Vol.15, No.2, 79 https://doi.org/http://dx.doi.org/10.2139/ssrn.2222608

[46] Uwuigbe, U., O.R. Uwuigbe and P.S. Daramola, 2014. Corporate governance and capital structure: Evidence from listed firms in Nigeria stock exchange. Advances in Management, Vol.7, No.2, 44-49.

[47] Wahyuningtyas, E. T. (2018). A Study of Financial Stability, Nature of Industry and Rationalization in Earning. 2009, $262-266$.

[48] Wan Mohammad, W. M., Wasiuzzaman, S., \& Nik Salleh, N. M. Z. (2016). Board and audit committee effectiveness, ethnic diversification and earnings management: a study of the Malaysian manufacturing sector. Corporate Governance (Bingley), Vol.16, No.4, 726-746. https://doi.org/10.1108/CG-06-2015-0085

[49] Yendrawati, R., Aulia, H., Prabowo, H. Y., Indonesia, U. I., Indonesia, U. I., \& Indonesia, U. I. (2019). Detecting the Likelihood of Fraudulent Financial Reporting : Asia-Pacific Management Accounting Journal, Vol.14, No.1, 44-68.

[50] Yusoff, H., \& Mara, U. T. (2019). The Influence of Corporate Governance on Corporate Social Responsibility Disclosure: A Focus on Accountability. Academy of Accounting and Financial Studies Journal, Vol.23, No.1, 2635.

[51] Geis, G. (2011). White-collar and corporate crime: a documentary and reference guide. ABC-CLIO.

[52] Freire, C. (2019). Duality CEO-Chairman and its Relation with the Effectiveness of the Board Control. https://doi.org/10.21511/ppm.17(4).2019.20.

[53] Nuanpradit, S. (2019). Real earnings management in Thailand: CEO duality and serviced early years. Asia-Pacific Journal of Business Administration, 11(1), 88 108. https://doi.org/10.1108/APJBA-08-2018-0133. 